Tragedy

\section{The banality of tobacco deaths}

\section{S Shatenstein, S Chapman}

\section{The attacks on 11 September 2001 and the subsequent anthrax scare have provided twin lessons in the perils and possibilities of tragedy}

\section{Thrift, thrift, Horatio! The funeral baked meats}

Did coldly furnish forth the marriage tables

William Shakespeare, Hamlet, Act I, Scene II

The king dies and his son Hamlet mourns. Hamlet's grief is increased by his mother's unseemly haste to marry her late husband's brother. She has calculated too coldly. Health advocates are not evil plotters, but their motives and actions have sometimes been likened to those of Queen Gertrude and King Claudius. The question arises: should they profit from tragedy? And can the tobacco control community appropriate dramatic images for its denormalisation campaigns and not alienate the public?

The 11 September attacks in New York and Washington, and the subsequent anthrax scare, have provided twin lessons in the perils and possibilities of tragedy. The bonds of faith, family, and community can be shattered or strengthened in suffering's wake. In similar fashion, tobacco control advocates' messages can be emboldened, weakened or even repudiated by their proximity to disaster.

Tobacco control has had the dismal luxury of unimaginably "great" statistics to make its case. Globally, an estimated four million people die each year from tobacco related illness, ${ }^{1}$ compared to 2.7 million from malaria, ${ }^{2}$ and 2.8 million from AIDS. ${ }^{3}$ After deaths from malnutrition (5.9 million in 1990) $)^{1}$ and violence and injury (5.8 million), ${ }^{4}$ tobacco claims more deaths than any other single cause. Between 1950 and 2000, it was estimated that smoking caused about 62 million deaths in developed countries $(12.5 \%$ of all deaths: $20 \%$ of male deaths and $4 \%$ of female deaths). More than half of these deaths ( 38 million) will have occurred at ages 35-69 years. Currently, smoking is the cause of more than one in three $(36 \%)$ male deaths in middle age, and about one in eight (13\%) of female deaths. Each smoker who dies in this age group loses, on average, 22 years of life compared with average life expectancy. ${ }^{5}$ By 2020, the World Health Organization estimates that "the burden of disease attributable to tobacco will outweigh that caused by any single disease ${ }^{\prime \prime}{ }^{6}$
Those are numbers, well, to die for, but they fail to create a sense of urgency in the media, nor among policymakers and the public. As Joseph Stalin argued: “A single death is a tragedy, a million deaths are a statistic." Beatle George Harrison's death on 29 November 2001 from smoking induced cancer was noted as much as if he had died from any other cause, despite losing more than 20 years off the average life expectancy of a 58 year old man (fig 1). Indeed the ABC network in the USA went so far as to note that unlike many other rock stars (Hendrix, Joplin, Morrison) Harrison had died of "natural causes". Eighteen years ago, Alan Blum reflected on community and political complacency about tobacco's death toll in an editorial titled "If smoking killed baby seals ...". ${ }^{7}$ Smokers are not, by and large, cuddly little things with plaintive round eyes. Their deaths, by cancer, heart disease and respiratory distress, tend to be quietly painful affairs, remarked only by those who knew and loved them.

Tobacco control advocates have long tried to make smoking statistics resonate with a public numbed by endless quantification rhetoric advanced by myriad interest groups. Annual tobacco deaths in different nations have been routinely compared with deaths from so many

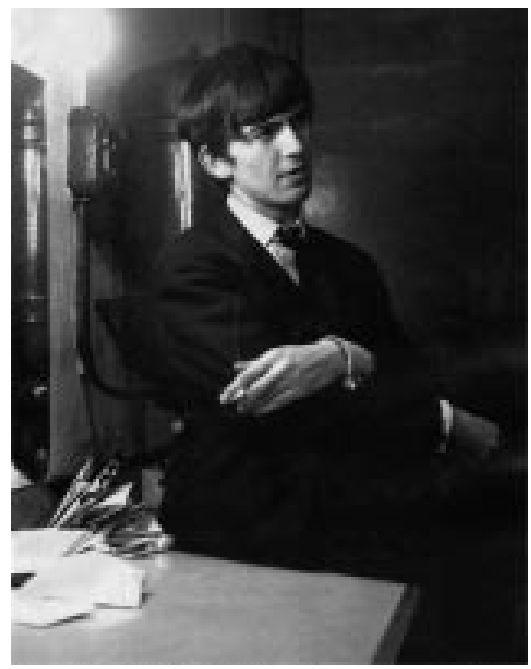

Figure 1 Former Beatle George Harrison, who died 29 November 2001 from tobacco induced cancer. Photograph: Jane Brown, Camera Press, London jumbo jet crashes, the loss of football stadium crowds, and the obliteration of entire medium sized cities. Conferences and shopping centres display digital death clocks for tobacco where audiences and shoppers transfix on the ever mounting toll.

But, for all this, community concern about health problems can reach its zenith over low probability threats that barely rate an asterisk on national causeof-death tables. Risk communication research shows that exotic, involuntary, catastrophic, and sudden risks strike fear into the heart far easier than chronic, day-in-day-out dangers like smoking ${ }^{8}$. Folk wisdom tells us that a small sum spent on prevention is worth a fortune spent on cures, but cancer charities know which emphasis will see larger banknotes flow into collection buckets. Governments, with eyes firmly trained on the next electoral cycle, continue to give budgetary priority to acute health problems. Politicians wish to cast themselves in rescue fantasies where grateful patients and their families form the backdrop to photo opportunities. And the news media are generally happy to perpetuate these myopic myths. One person killed after ingesting the contents of a contaminated tin of food can be more newsworthy than 4 million dying the world over, each and every year, from consuming tobacco products off bought off the same store shelves.

Alan Moir's telling cartoon (fig 2), published in the Sydney Morning Herald in the first days of the anthrax mailings in the USA, shows a group of smokers reading the banner coverage of a single death attributed to anthrax. As we go to press, five people have died as a result of anthrax inhalation. Figure 3 shows an anti-smoking poster plainly appropriating the New York twin towers outrage. Accompanied by a simple call for "No more killing", two upturned cigarettes burn in the shape of the World Trade Center before their collapse. Produced in Hong Kong by graphic artist Michael Miller Yu and designer Eric Chan, tobacco control groups there and elsewhere refused to endorse it, branding it

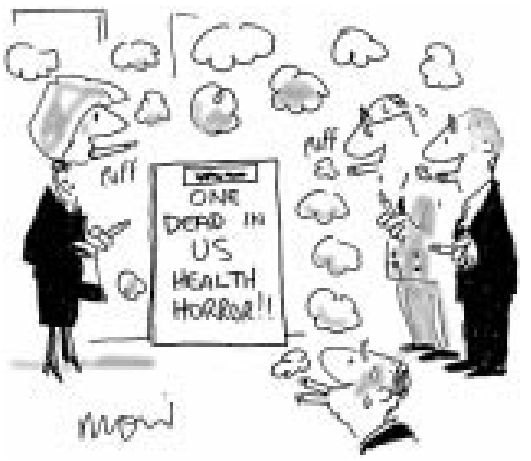

Figure 2 Cartoon by Alan Moir, which appeared in the Sydney Morning Herald 
as gratuitous, "cheap, sensationalist and 100 per cent exploitative". ${ }^{\prime}$ Hong Kong Council on Smoking and Health (COSH) chair Professor Tony Hedley, with an understandable eye toward such sentiments, said, "we want people to look at tobacco deaths on their own merits". ${ }^{10}$

However just three weeks later former US Surgeon-General C Everett Koop translated tobacco's toll into a "Trade Tower fiasco" equation. ${ }^{11}$ There is a saying that tragedy plus time equals comedy. Hitler was not the best subject for comedy right after the second world war, but the Third Reich eventually became the subject of the movie and stage comedy, The Producers, and an American TV sit-com, Hogan's Heroes. Perhaps Dr Koop has signalled that the time for a changed sensitivity about terrorism versus tobacco has come already.

It is a journalistic maxim to declare that "if it bleeds, it leads". Tobacco control advocates don't have the sanguinary "luxury" of bold headlines to make their case, but they are not evil plotters. Their cause is relatively simple: smoking kills an obscenely large number of people, about half in middle age. But while smoking kills in large numbers, it does so one quiet, private death at a time. A single jumbo jet crash that kills 300 people makes the front pages for days. The Towers' collapse and anthrax deaths have created a climate of fear that will forever mark the generations that have been through it "live". The "excess mortality" deaths of 300, 3000, or 30000 tobacco users go relatively unnoticed, except by the smokers' grieving relatives. Hannah Arendt wrote of the banality of evil among the very "ordinary" men who perpetrated the Nazi atrocities. ${ }^{12}$ Tobacco deaths have their own banality in desperate need of redefinition so that communities may become out-

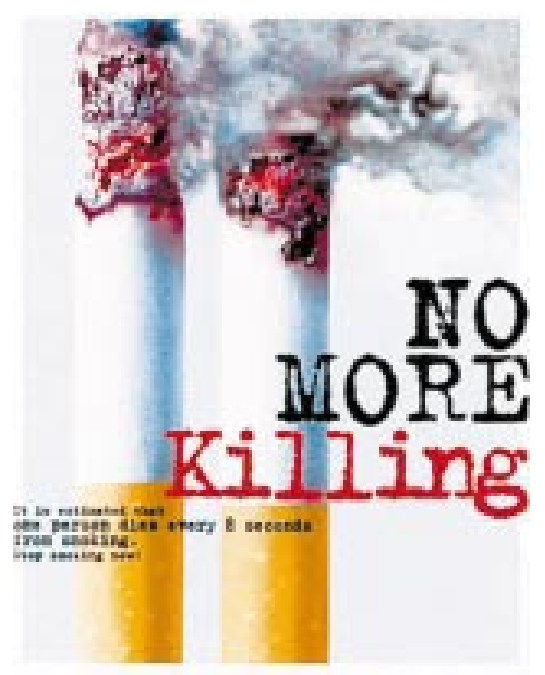

Figure 3 Anti-smoking poster produced in Hong Kong by graphic artist Michael Miller $\mathrm{Yu}$ and designer Eric Chan. Local tobacco control groups refused to endorse it. raged in the face of industry misconduct and government inaction.

Whatever we think of the tobacco industry, it would be unfair to claim that, like terrorists, they hope their victims will die. However, the industry certainly knows that up to $50 \%$ of its users will, in fact, die as a result of using its products. It has spent decades knowingly and falsely reassuring smokers that they should not worry too much about "statistics" while also opposing every serious tobacco control measure in all global jurisdictions. This is not called terrorism, because the tobacco industry does not intend to strike fear and horror into people's hearts. But its behaviour is undeniably, appallingly criminal, on both the corporate and individual levels.

The tobacco industry does not slow its rapacious campaigns to recruit and sustain its customer base, and the resistance may need to be just as muscular. From Australia's aorta TV ad (see image at http://www.quitnow.info.au/) to Canada's diseased gums package warning label, it's already taken some loud, even shocking images ${ }^{13}$ to steal a march on the industry. There is a constant need to be forcefully creative, while avoiding insensitivity.

The Twin Towers have fallen, the clean up continues. The anthrax spores leave the mail system, but the investigation proceeds. And tobacco's toll grows higher, but the battle against the industry progresses slowly and fitfully. "It is estimated that one person dies every 8 seconds from smoking", reads the fine print on the Hong Kong poster. Can any presentation of that message be more shocking than the number itself?

Tobacco Control 2002;11:1-2

\section{Authors' affiliations}

S Shatenstein, Editor, GLOBALink Tobacco News

S Chapman, Editor, Tobacco Control

Correspondence to: Professor Simon Chapman, Department of Public Health and Community Medicine, Edward Ford Building A27, University of Sydney, NSW 2006, Australia: simonc@health.usyd.edu.au

\section{REFERENCES}

1 Murray CJL, Lopez AD, eds. The global burden of disease. A comprehensive assessment of mortality and disability from diseases, injuries and risk factors in 1990 and projected to 2020. Harvard: Harvard University Press, 1996

2 Breman JG, Egan A, Keusch GT. The intolerable burden of malaria: a new look at the numbers. Am J Trop Med Hygiene 2001;64(1-2 suppl):iv-vii.

3 United Nations Programme on HIV/AIDS Report on the global HIV/AIDS epidemic June 2000. URL: http://www.unaids.org/ epidemic_update/report/glo_estim.pdf

4 World Health Organization. Violence and injury prevention. URL: http://www.who.int/ violence_injury_prevention/injury/burden.htm

5 Peto R, Lopez AD, Boreham J, et al. Mortality from tobacco in developed countries: indirect

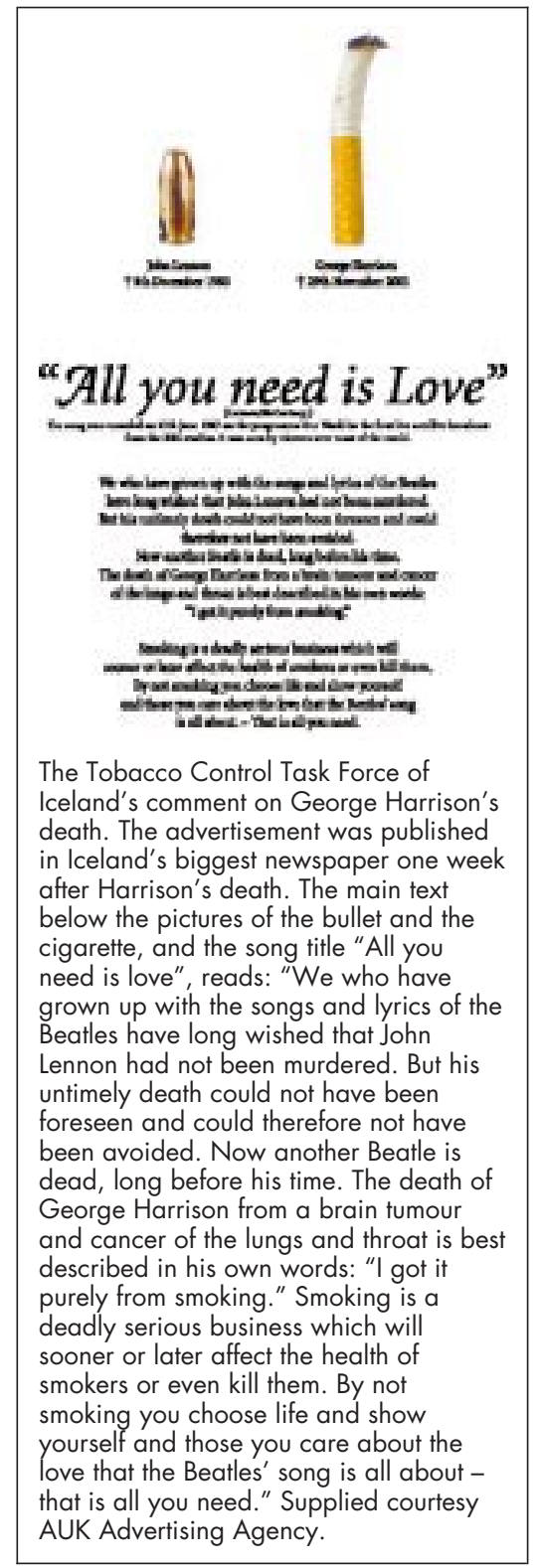

estimation from national vital statistics. Lancet 1992;339:1268-78.

6 World Health Organisation. The global burden of disease. URL: http://www.who.int/ $\mathrm{msa} / \mathrm{mnh} / \mathrm{ems} /$ dalys/intro.htm

7 Blum A. If smoking killed baby seals . . .NY State J Med 1985;85:282-5.

8 Slovic $\mathbf{P}$, ed. The perception of risk. London: Earthscan, 2000.

9 Nicols $M$. Anti-smoking ad featuring attacks on US condemned. The Scotsman 3 November 2001.

10 Schwartz S. Shock anti-smoking poster rejected. South China Morning Post 2 November 2001.

11 Koop CE. Press conference remarks. Launch of $\mathrm{NCl}$ Monograph 13: Risks associated with smoking cigarettes with low machine-measured yields of tar and nicotine, Washington DC, 23 November 2001.

12 Arendt H. Eichmann in Jerusalem; the banality of evil. New York:Viking, 1963.

13 Mahood G. Warnings that tell the truth: breaking new ground in Canada. Tobacco Control 1999;8:356-61. (see also http://www.nsra-adnf.ca/english/ warnoverview.html) 